\title{
Natalia Sineaeva-Pankowska
}

\section{Visitors' Reactions to the Holocaust Gallery: From the guide's notes}

The Holocaust gallery is a part of the permanent (core) exhibition of the Polin Museum of the History of Polish Jews. The core exhibition consists of the symbolic "Forest" and seven historical galleries (covering the period from the $10^{\text {th }}$ century to post-war times) that present the thousand year history of the Polish Jews. A conceptual framework for the Holocaust gallery was developed by two distinguished Polish scholars, Professors Barbara Engelking and Jacek Leociak. $^{1}$

The Polin Museum has been created as a space for dialogue, reflection, and critical analysis of the past. As Konstanty Gebert states: "It is a museum of questions." 2 According to Piotr Piotrowski's categorisation, the Polin Museum may be considered as a "forum museum" designed to contribute to the building of an open society. ${ }^{3}$ It illustrates how a previously marginalised minority narrative (of Jewish history) may be incorporated into the dominant discourse and memory of the larger (national) culture. The Polin Museum may also be seen from the point of view of the multicultural heritage and history of Central and Eastern Europe. One may say, quoting Prof. Barbara KirshenblattGimblett, that [the museum tells] a story that is not just Polish and Jewish, but also universal. ${ }^{4}$

The subject of the Holocaust, being both a chapter in the millennial history of Jews in Poland and a turning point in the history of our civilization, ${ }^{5}$ constitutes a fundamental issue for the Polin Museum. The gallery devoted to the Holocaust is divided into several parts, each illustrating a different chapter of the Holocaust: Prologue depicts the outbreak of World War II and the beginning of the German

\footnotetext{
${ }^{1}$ Justyna Majewska, Kamila Radecka-Mikulicz, and Maria Ferenc-Piotrowska serve as curators of the Holocaust Gallery.

2. From Konstanty Gebert's lecture delivered during the first series of the POLIN Academy Summer Seminars (PASS), August 2013.

${ }^{3}$ From Museum Critique to the Critical Museum, eds. Katarzyna Murawska-Muthesius, Piotr Piotrowski, London: Routledge, 2015.

${ }^{4}$ Natalia Sineaeva-Pankowska, "Wywiad z Barbarą Kirshenblatt-Gimblett," Evreiskaya Gazeta (Berlin), November 2013.

${ }^{5}$ An expression coined by Jana Tomasz Gross.
} 
and Soviet occupations linking this gallery with the previous part of the core collection. The Separation and Isolation Hall documents the status of Polish Jews from the beginning of the German occupation to 16 November 1940, the day on which the Warsaw ghetto was sealed. Ghetto 1 (Labyrinth) chronicles life in the shadow of death in the Warsaw ghetto from November 1940 to the Great Deportation in July 1942. This part of the gallery focuses on particular aspects of ghetto living: social care, economy, diseases, culture, religious life, police and collaboration, and underground activities. Excerpts from the diaries of two of the ghetto's most prominent figures: Emanuel Ringelblum, creator the ghetto's archive Oyneg Shabes (Oneg Shabbat), and Adam Czerniaków, chairman of the Jewish Council, provide commentaries on each of the topics above. The Symbolic Bridge opens a view onto the so-called 'Aryan side'. Ghetto 2 explains the events of the Great Deportation and the Warsaw Ghetto Uprising. The Aryan Side shows the war and occupation as seen through the eyes of Poles: the German terror, the Polish Underground State, the Polish-Jewish relations and organised help for Jews ('Żegota', the Jewish National Committee). Hiding tells stories of Jews hiding in the Aryan part of Warsaw, as well as those 'hiding in plain sight', i.e. living 'on Aryan papers'. East. The Holocaust of Polish Jews. The Holocaust of European Jews, which presents the narrative that begins on 22 June 1941, the day of the German attack on the Soviet Union, focuses on the activities of the SS death squads, the Einsatzgruppen (Bialystok, Pińsk, Stanisławów, Ponary), local pogroms (Jedwabne, Lwów), Kulmhof (Chełmno nad Nerem, where the first exterminations were conducted), and the conference in Wannsee. Shoah, which is devoted to the death camps Auschwitz II-Birkenau and Treblinka II. This section of the gallery ends with four photographs in their original sizes, secretly taken by members of the Sonderkommando in Birkenau. Finally, The Corridor/The Hall with its emptiness serves as a symbolic image of the end of the Holocaust. The stories of the end of World War II and the liberation of the extermination camps are told in the post-war gallery.

The Holocaust gallery is situated between the two galleries that show Jewish life before and after the war: On the Jewish Street (1918-1939) and Postwar Years (1944 to present). This design, which helps the audience to understand the sequence, origin, and consequences of events, distinguishes this exhibition from others presented in Holocaust museums around the world. The genius loci of the place also contributes to its uniqueness as it is where Zamenhof Street ran before and during the war, the same street that Jews were forced to walk along on their way to the infamous Umschlagplatz, from which the trains departed for the extermination camps. This gallery has been designed primarily to present these events as if viewed through the eyes of victims, allowing visitors to learn about the Holocaust gradually, the way its victims did. Additionally, some quotes from journals and chronicles exhibited throughout the gallery expose viewers to the language of the time, offering them a deeper, more empathetic connection (co-feeling) to the victims. 
The main objective of my paper is to summarise the period of a year and a half since the opening of this exhibition in October 2014. This summary is written from the point of view of museum guides, and incorporates their early observations made in the course of interactions with visitors. As it is impossible to document every aspect of the gallery's impact on its audience, I will try here to focus on these observations made by the guides that may be of potential interest to a broader readership as well.

I will try to answer the question about the role that the Holocaust gallery plays in the narrative of the core exhibition and show how that influences the routine of museum guides. The guides are expected to complete a tour of the core exhibition in two hours, which takes into account time constraints and the average capacity of visitors' attention span, allowing for no more than 15-20 minutes for each gallery. Despite the time limitation, the guides often face many difficult questions from patrons. I will identify topics, which remain particularly sensitive to Polish visitors, as well as these which have already found their place in Polish public discourse. I will also detail subjects the audience shows interest in learning more about and understanding better. Having in mind that the school groups constitute a substantial share of the museum's visitors, I wish to take up the question of how a guide can utilise the educational potential of the gallery during a standard two hour tour. ${ }^{6}$ What can the gallery offer to guests from other countries that have also experienced genocide? What is its significance for young people and adults who arrive at the museum in groups as participants of the March the Living? Is there a difference between the experience of Polish visitors to the gallery and that of visitors from other parts of the world (Jewish and non-Jewish), especially those from Eastern European countries (e.g. Moldova, Romania, and Ukraine)?

This last question is of particular importance to me personally as I come from Moldova and, for many years, I have been involved in efforts to memorialise the Holocaust and stand up against Holocaust denial in the context of Eastern European history.

I began as activist with the Antifascist Democratic Alliance working alongside Holocaust survivors. Later, I worked for $\mathrm{Nu}$ voi uita, the only Moldovan periodical devoted to the history and memory of the Holocaust, ${ }^{7}$ which was created during a time in which the subject of the Holocaust was not part of the public debate in Moldova (the periodical has since ceased publication). Later, when I was already in Poland, I became actively involved in the work of the anti-racist organisation Never Again [Nigdy Więcej] founded by Marcin Kornak in the mid-1990s. Finally,

\footnotetext{
${ }^{6}$ Here, I focus only on the museum guides and their work in the Holocaust gallery. The Polin Museum, however, organises additional workshops for students of different educational levels. The workshops are held in the core exhibition area and in the educational room.

7 'We Will Not Forget'; Efim Tcaci, Moldavian musicologist, music critic, and a Holocaust survivor was the editor-in-chief of the periodical.
} 
the subject of my doctoral thesis, on which I am currently working, concerns the memory of the Holocaust in Eastern Europe using Moldova as an example.

As I work as an educational specialist - a guide at the Polin Museum, the material presented in this paper has been gathered using participant observation. Although the opinions expressed in the article are the author's alone, I have interviewed other guides employed at the Polin Museum who are quoted herein.

\section{Who visits the Museum?}

Nearly half a million people, Poles and foreigners of all ages, visited the core exhibition (including the Holocaust gallery) from its opening in October 2014 to the end of May 2016 when this paper was completed. A profile of the museum visitors, both individual visitors and organised groups, ranged from school children and students to participants of the third age universities (U3A), professionals, old and young, Jews and non-Jews, locals, and visitors from other parts of Poland and from abroad. ${ }^{8}$

As a rule, international guests primarily visit in organised groups, mostly from Israel, the United States, Germany, France, and less frequently from Eastern Europe: Ukraine, Russia, Belarus, Lithuania, and Moldova. According to an internal survey conducted by the museum, among the most frequent reasons for visiting the museum are: a desire to broaden knowledge, an interest in Jewish culture or the museum itself, and recommendations from family or friends. The group visitors from abroad were more likely to mention the memory of the Holocaust as their primary reason of interest. ${ }^{9}$ Our visitors explore the core exhibition independently, use the audio guide, or participate in guided tours. ${ }^{10}$

\section{Who are the guides and what do they do?}

Initially, the museum hired six guides, educational experts and graduates of the first 'edition' of the Polin Academy, a one-year preparatory training programme for working in the museum held in 2013. Since the opening, two additional 'editions' of the course have been organised to train freelance guides. (At present, 88 people are certified to act as guides for the exhibition).

\footnotetext{
${ }^{8}$ The internal survey conducted by Marek Łoś of the Polin Museum Marketing Department between May and December 2015 showed that $61 \%$ visitors were residents of Poland and $39 \%$ came from abroad. The highest number of visitors $(27 \%)$ were between the ages of 14 and 24 years old; $24 \%$ were between 35 and 50; $23 \%$ between 25 and 34; $16 \%$ between 51 and 64 years old; and $11 \%$ were 65 old years or older.

${ }^{9}$ Ibidem.

${ }^{10}$ The survey conducted by the Polin Museum's Marketing Department showed that, in visitors' opinions, guided tours resulted in a better grasp of the core exhibition than selfguided tours (45\% prefer guided tours, 33\% prefer to explore without a guide).
} 
From November 2015 through to the end of March 2016, the guides led over 4,000 groups around the museum (I myself guided over 400 groups, that is about 5,000 people; each of the resident guides conducted a similar number of tours). In addition, freelance guides are allowed to (and do) tour their own groups.

The process of becoming a museum guide is challenging and includes several steps (among them a history test and separate exams for separate galleries, a Holocaust gallery test is mandatory), so applicants need to demonstrate a lot of tenacity and self-motivation.

The group of museum guides is diverse and includes professional city guides as well as experts in various fields related to the subject of the museum, including historians, sociologists, and cultural studies specialists. The museum attracts people who, above all, are open to dialogue and willing to examine 'difficult' topics. In today's Poland, the museum is one of a few institutions of this status and importance, in which critical analysis and discussion of the past are possible.

Each guide has his or her story to tell about what has drawn him or her to the Polin Museum. Here are some examples.

Barbara Subko, freelance guide:

Why do I wish to work in the museum as a guide? It is a logical consequence of my prior experience. I subscribe to the Polin Museum's philosophy. I am part of a generation that identifies itself with the democratic transition. I am of the same generation as Barbara Engelking and Jacek Leociak. In our school days, the topics of Jews and the Holocaust were regarded as taboo, so our interest in them only came later, [together with] our understanding of the not confronted past. Then the books of Jan Tomasz Gross were published, and with them I began to mature into this kind of work. On a daily basis, I encounter longstanding stereotypes and prejudices that require my critical thinking. I engage in it in the school where I work, but also in the museum, where I show Polish and foreign (mostly French) groups around.

A guide, Julia Chimiak, says on the same subject:

I met Prof. Jean-Yves Potel when I was a student majoring in French. He wrote a book on Polish-Jewish relations and looked for someone who could accompany him during his interviews, to serve as an interpreter and select and translate press articles (Jan Gross's Fear was published and debated at the time). That gave me an opportunity to meet and listen to many wonderful people from around Poland, who had studied the PolishJewish past and its memory, or contributed to the contemporary Jewish culture in Poland. The publishing house, Znak, published my translation of Potel's book entitled Koniec niewinności. Polska wobec swojej żydowskiej przeszłości ${ }^{11}$ [The End of Innocence. Poland Facing its Jewish Past]. To

${ }^{11}$ Jean-Yves Potel, La fin de l'innocence: La Pologne face à son passé juif (Paris: Frontières, 2001). 
do the translation work I needed to study the subject thoroughly, as I understood that I would be participating in the creation of a new way of looking at Polish-Jewish relations and the history of Jews in Poland, and I wanted to share my knowledge with others. My work at the museum offers me the opportunity to do so.

Mariusz Jastrząb, a guide at the Polin Museum:

My interest in the history of the Jews began when, as a student, I attended lectures by Natalia Aleksiun, and a seminar by Marcin Kula, in which these subjects were discussed. I had also grown up in Muranów and was interested in the history of this district of Warsaw. The history of this district has a different meaning for me than for Beata Chomątowska, whose book I have read. ${ }^{12}$ I approach it in a more personal way as it is part of my history, whereas she came here from Cracow as an adult. I feel attached to this place. I remember that there was no trace of the ghetto there, when I was growing up; it had somehow been pushed out of [our] consciousness. I also remember clearly when the memorial trail and monument on the Umschlagplatz were built in 1988.

Similar personal accounts may influence an entire narrative, as each guide can weave into it his or her personal story. The most frequent questions visitors ask their guides, usually at the very beginning of the tour, concern the guide's motivations and background. The guests are always interested in the personal motivation of the guides.

As I have mentioned, the guided tour of the core exhibition, which stretches over 4,000 square metres (almost 4800 sq yards), takes two hours, assuming groups spend 15-20 minutes in each gallery. During the two-hour tour, guides should introduce the context of each gallery (presenting its guiding principles, historical background, and the most important topics selected by its curator), and should set aside time for questions and answers. As a rule, guides spend the first hour of the tour showing the first four galleries, while the next hour is reserved for the last three. Often, noticing that visitors are getting tired in the middle of the tour and their level of attention is falling; guides suggest a break in the gallery On the Jewish Street. Other times, the groups themselves ask for a break. Under such circumstances, the guides face the challenge of how to present the complex topics of the final two galleries (Holocaust: 1939-1945 and Postwar Years: 1944 to the Present) in a comparatively short time and retain the interest of their tired audiences.

The guides need to take into account that visitors, both Polish and foreign (especially non-Jewish), often come to the museum with knowledge about the Holocaust that is general and taken out of its historical context. Sometimes, they may feel lost, not understanding the chronology of events. As they wish

${ }^{12}$ See Beata Chomątowska, Stacja Muranów (Wołowiec: Wydawnictwo Czarne, 2016). 
to deepen their knowledge and understand better the mechanisms and events surrounding the Holocaust, all groups (including the Jewish ones) stay longer in the Holocaust gallery.

The results of the visitor survey that the museum has conducted confirm these observations. The majority of the visitors questioned (27\%) wish to spend more time in the Holocaust gallery; $20 \%$ in the The Jewish Town gallery; $19 \%$ in the On the Jewish Street gallery; $12 \%$ in the 19th-century Encounters with Modernity gallery; 9\% in the First Encounters gallery; 7\% in Paradisus Iudaeorum gallery; $6 \%$ in the Postwar Years gallery; and 3\% - in the Forest gallery. ${ }^{13}$ According to the same survey, the parts of the exhibition that depict the Holocaust and the Jewish street remain the most memorable to the visitors. ${ }^{14}$

\section{What makes an impression on the visitors? \\ What do they think is missing? \\ What do they want to know?}

I have noticed that visitors have a strong emotional response to the actual architectural form of the Holocaust gallery. In this context, they first mention the view from the 'Symbolic Bridge' (the footbridge over Chłodna Street that connected the two parts of the ghetto, enabling the Jews who crossed it to perhaps get a glimpse of life on the so-called 'Aryan side'), but they also respond to the 'Labyrinth' and the narrow passage leading to the Umschlagplatz (the names of ghetto's streets are written on its descending steps), and finally the long and dark Shoah Hall. The viewers repeatedly reported a strong emotional reaction to the pictures taken in Ponary and other locations where 'Shoah by bullets', (the massacres of Jews committed by the Einsatzgruppen) took place. This exhibition is a powerful example of an iconic mode of experience in which films, maps, images, and photographs capture viewers' imaginations thereby serving as a tool to convey information. ${ }^{15}$ Thus, the gallery offers its patrons not only an emotional experience, but also information related to this experience (as they see the Holocaust mainly through the eyes of the victims), and a memory experience (as they learn firsthand, for example, that Jews went to the Umschlagplatz via Zamenhof Street).

Some visitors from abroad were struck by the various quotes displayed throughout the exhibition. Professor Daniel Nkemleke from Cameroon, for example, stated that he had been moved by Rabbi Shapira's quote about God: "...we believe that You save us, that You have not forsaken us completely, God forbid. But, in feeling 'forsaken' we refer to our salvation that is so far away and the suffering that goes on and on [...] But how can You bear the humiliation of the Torah and the pain of the Jewish people, who are being tortured only because they

\footnotetext{
${ }^{13}$ Survey conducted by the POLIN Museum's Marketing Department.

${ }^{14}$ Ibidem.

${ }^{15}$ Anna Ziębińska-Witek, Historia w muzeach. Studium ekspozycji Holokaustu (Lublin: Wydawnictwo UMCS, 2011), p.155.
} 
observe the Torah?"16 The scholar believed that the citation referred to an issue fundamental to many theologies: "Why do we suffer? Why would a benevolent God allow His children to undergo such suffering unaided?" In a letter, Professor Nkemleke wrote to his guide, he stated: "[This museum is] a remarkable place for the recollection of memory, an asset that is indispensable to building bridges of peace into the future. I think that your services as a guide to tourists in the Museum are a true service to the victims, their families, and to society."17

Many visitors, both foreign and Polish, were surprised by the number of ghettos set up in Poland - the list of 600 locations illustrates to them the immensity of the crime. They were also surprised that so many people had been deported from the Warsaw ghetto to Treblinka during such a short period in the summer of 1942. (The number of the deported is displayed on the wall above the steps leading to the Umschlagplatz).

I have noticed that viewers, once again, foreign and Polish alike, are often interested in learning about other ghettos, e.g. ones from their own hometowns. Other guides can confirm my observation:

Anna Kraus: "Visitors from Poland often search the list of the ghettos for the name of their city. Standing in front of the map, they share information about the ghetto in their neighbourhood."18

Julia Chimiak:

Groups coming from abroad or from outside of Warsaw often cite a lack of examples that could be helpful in explaining the history of ghettos in their own towns, or enable comparison of the situations in different ghettos. Sometimes they address this absence directly. Several groups that included survivors from outside Warsaw (e.g. from Sosnowiec) were especially distressed by this omission. They found it difficult to understand that the exhibition at the Museum of the History of Polish Jews hardly mentioned the place to which they had been confined during the war, reducing it to just a name among many in the long list of the ghettos. There are quotes displayed on the mezzanine, but they come from just a few places, and there are only a few of them. I think it is understandable and justifiable to choose Warsaw as an axis of the gallery narrative, but I can also appreciate the resentment of the visitors whose wartime experience tied them to other places. ${ }^{19}$

Some guests participating in the regular gallery tours voiced their desire to hear personal narratives, to learn more about the experiences of individual victims. As a high school freshman from Płońsk put it: "I think it would be a good idea to provide more detailed information about the Jewish inmates in

${ }^{16}$ Translation by J. Hershy Worch, see: Kalonymus Kalmish Shapira, Sacred Fire: Torah from the Years of Fury 1939-1942 (Lanham: Jason Aronson, 2002), p. 289.

${ }^{17}$ From a letter from Daniel A. Nkemleke, 16 May 2016.

${ }^{18}$ Interview with Anna Kraus, 31 March 2016.

${ }^{19}$ Interview with Julia Chimiak, 16 March 2016. 
extermination camps and those who fled from transports. I entered the exhibit aware of these events, but I still learned a lot of new things. The museum should present more personal stories." ${ }^{20}$ Her peers expressed similar sentiments: "The visit to this museum encouraged me to learn more about the history of the Holocaust. The exhibit made me aware of the pain and suffering of these people, their fear and uncertainty of the unknown. Would like to learn more about all sorts of personal stories and about those who survived the Holocaust." "I would like to understand better what life in extermination and labour camps was like and how people coped with the knowledge of their impending death." "The exhibit is well designed, but it needs more personal accounts of Jews."21

It is also worth noting here that many guests, both foreign and Polish, have inquired into the possibility of touring the gallery accompanied by Holocaust survivors (a common practice in other Holocaust museums).

Some visitors maintain that the gallery does not show disturbing images, that it is very tame and well-thought-out. Although the exhibit does provide information on the number of deported Jews, one teacher, who took the regular tour, commented afterward: "It seems to me that the Holocaust part [of the museum] does not emphasise the magnitude of the number of Jews murdered."22

\section{Polish Groups}

The school groups (mostly junior high schools and high schools, and less often elementary schools) constitute most of the Polish groups led by other resident guides and me. These groups present the biggest logistical and professional challenge for us. It is difficult to keep students focused for two hours, as they may already be tired after visiting other Warsaw museums. But still, unlike museum educators, guides cannot select one or two topics to talk about in one or two galleries. They must walk their groups through the entire exhibition.

The most challenging aspects of leading such groups, and one that guides have faced from the very beginning, involved the age at which one can talk about the Holocaust to elementary school students. ${ }^{23}$ How does one adequately explain difficult topics, taking into account things students do not know anything about (for example, Jedwabne), or that their knowledge reflects stereotypical beliefs prevalent in their circles. It is not uncommon for students to ask immediately

${ }^{20}$ Opinion of a visitor, a freshman from the Henryk Sienkiewicz High School in Płońsk, April 2016.

${ }^{21}$ Opinions of visitors, students from the Władysław Anders High School (HS 62) in Warsaw, April 2016.

${ }^{22}$ Opinion of a visitor, a teacher from the Władysław Anders High School (HS 62) in Warsaw, April 2016.

${ }^{23}$ Sometimes elementary school teachers who chaperone groups of 11-13-year do not want to postpone visiting the Holocaust gallery until the students are older and ask their guide to include it in their group's itinerary. 
upon entering the gallery, "Will there be anything about Jedwabne?" Several times, students have also asked me why Jews worked for the Germans instead of defending themselves.

Junior high school (gymnasium) groups are more demanding than high school students, who sometimes are well prepared and interested in the subject. A lot depends on their teachers. Some expect their students to focus and learn something that is important, others view the museum as merely a tourist attraction, just another stop on the school trip itinerary. Sometimes, teachers expect their guide to put forward fairly detailed narratives of very complex issues, among them the pogroms in Jedwabne and surrounding towns, post-war violence, and the outburst of anti-Semitism in March 1968. Once, I gave a tour to a very well-prepared group of junior high school students from Lębork. They had discussed Anna Bikont's book The Crime and the Silence: Confronting the Massacre ofJews in Wartime Jedwabne with their teacher on the train to Warsaw. This, however, remains the exception rather than the rule.

One of the methods that can be effective when working with school groups is interactive guiding that uses various educational elements to help build empathy for the victims. The Holocaust gallery is the ideal place to employ this technique. At the very beginning of the tour, in the Separation and Isolation Room, I ask students what it would feel like to wear armband, (which all Jews older than 12 were required to wear on their right arm). A quote from the diary of Aleksandra Sołowiejczyk-Gutter serves as a starting point for the discussion. Later on, on our way through the Labyrinth of the ghetto, I engage them in conversation, asking what life in the ghetto might have been like. Standing on the symbolic bridge over Chłodna Street, I encourage students to imagine what Jews might have felt looking at the so-called 'Aryan street'. The subject of Jedwabne provides an opportunity to ask whether bystanders can also become perpetrators. The same topic can be re-examined later, in the post-war gallery, where the words of Jan Błoński, ${ }^{24}$ which raise the question of 'shared responsibility' (when one can share the responsibility for the crime without directly taking part in it), are displayed. Young people engaged in two-way communication typically become more cooperative than when they listen passively to a lecture by a guide. In the process, the Holocaust gallery stimulates their emotional sphere, makes them more sensitive, and provokes reflection. One of the students attested to this. After participating in the interactively guided tour, he observed: "The gallery has a high impact on human sensitivity. In such a moment I can see the omnipresent need for empathy and understanding. Worthwhile [to see]."25

${ }^{24}$ From his article "Biedni Polacy patrzą na getto" first published in the Polish weekly, Tygodnik Powszechny on 11 January 1987. For the English version see: Jan Bloński, "The poor Poles look at the Ghetto," Polin 2 (1987): 321-336.

${ }^{25}$ Opinion of a visitor, a student from the Władysław Anders High School (HS 62) in Warsaw, 13 April 2016. 
A guide may wish to focus on children's lives while guiding school groups, and some relevant examples are to be found in the room devoted to the history of hiding. According to some visitors, however, the gallery does not show enough stories and images of children. Jeremy Jones, an Australian visitor, noticed: "The Jewish Museum in Australia uses a lot of stories of children; there are a lot of pictures of children there, and it makes a strong impression on the visitors." ${ }^{26}$

One of the guides shared an observation that there are more Polish literature teachers than history teachers among the educators who come to the museum with their students. They usually expect that, during the tour, their guide will make references to such literary works as To Outwit God by Hanna Krall, Campo di Fiori by Czesław Miłosz, or even Conversation with an Executioner by Kazimierz Moczarski. ${ }^{27}$ You can't find explicit literary references in the gallery, but guides (being allowed some latitude) are free to allude to them." ${ }^{28}$

During the first year after its opening, the museum was host to numerous groups representing different third age universities from all over the country; I worked with many of them.

These senior classes (like other ad hoc groups made up of individual visitors of all ages taking regular guided tours, usually on weekends), often constitute an inquisitive and demanding audience, looking for answers to a broad range of questions. I have noticed that participants of such 'non-compulsory' tours wish to spend more time in the museum. A two hour visit is definitely too short for them, some returning later on to explore each gallery in detail. Just after the opening, the regular guided tours were popular mainly among residents of Warsaw; now they are also in demand among other Polish visitors and foreigners.

Elderly visitors, including U3A attendees, tend to open up at the Holocaust gallery: they want to share their family stories, (about experiences in Siberia, among others) and wish to stress that not only Jews experienced hardships during the war, but gentile Poles as well. It has happened to me a few times, that visitors crossing the symbolic bridge were indignant at the depiction of 'normal' life on the Aryan side, ${ }^{29}$ and said that Poles had suffered as much as Jews had.

A resident guide, Mariusz Jastrząb emphasises that, as the U3A groups are more likely to express stereotypical views, he tries to make his narrative more emotional by telling them stories about hiding. The story of a boy, Jerzy Feliks Urman, who, when terrorised by szmalcowniks (blackmailers) swallowed

\footnotetext{
${ }^{26}$ Interview with Jeremy Jones 7 April 2016.

${ }^{27}$ To Outwit God, by Hanna Krall, an interview with Marek Edelman, the last surviving leader of the Warsaw Ghetto uprising, is mentioned in the Post-war Gallery (transl. Jaroslaw Anders, Evanstone, Ill.: Northwestern University, 1992); "Campo di Fiori," transl. Louis Iribarne, David Brooks, in: Czeslaw Milosz, New and Collected Poems, 1931-2000 (New York: HarperColins, 2003, pp. 33-35); Conversations with an executioner, transl. Mariana Fitzpatrick (Engelwood Cliffs, NJ: Prentice Hall, 1981).

${ }^{28}$ Interviews with Mariusz Jastrząb, 26 and 27 March 2016.

${ }^{29}$ Ibidem.
} 
a cyanide capsule, leaves a strong impression on audiences, as does an account of the events in Ponary.

Often, the groups walk through the Holocaust gallery in silence, asking questions only at the end of the tour. Typically, they ask rhetorical questions, "Why did such things happen?" "How can people do such things to others?" "How was the Holocaust possible?" Or they express some existential thoughts. ${ }^{30}$

They feel an urge to ask these questions aloud, to give voice to their emotions and experiences. We have noticed that visitors tend to be generally more relaxed, less focused on guide's explanations, or to talk amongst themselves while walking through the first galleries, but they are visibly moved and silent upon leaving the Holocaust gallery and entering the Post-war exhibit.

Polish visitors often voice opinions rooted in stereotype: "There were more righteous people in Poland than anywhere else, despite the fact that there was the death penalty [for helping Jews] in Poland but nowhere else." ${ }^{31}$ In this context, a guide, Anna Kraus, noticed: "When we discuss the attitude of the Polish population towards Jews during the Holocaust, quite often teachers chaperoning the school groups remind us about the Righteous Among the Nations." ${ }^{32}$ Similar sentiments are expressed in the symbolic 'tram' on the socalled 'Aryan street'. 'The tram' remains one of the most sensitive elements of the exhibition. Here, the guides discuss the range of attitudes held by Poles towards Jews during the war, showing indifference and passivity as the most common responses to the Jewish tragedy. It regularly provokes questions or remarks about Irena Sendler, Jan Karski, and sometimes Witold Pilecki. ${ }^{33}$ Occasionally, it leads to instrumentalisation of these symbols: the most meritorious examples, such as Irena Sendler or Jan Karski, are trivialised, reduced to patriotic clichés. Thus, the unique historical significance of these individuals can become lost.

Occasionally, visitors ask us to draw a comparison between the number of Jews murdered in the aftermath of the deportation of the Warsaw ghetto to the number of people killed during the Warsaw Uprising. Apparently, they see the Jewish and Polish martyrdom as being in competition with one another. Similar questions are asked by members of all kinds of groups: teachers, retirees, and individual visitors. I remember a military man who asked a question similar in character.

Surprisingly, the part of the exhibition devoted to the pogroms that took place in Jedwabne and some other neighbouring towns in the summer of 1941, arouses fewer emotions in the audience than might be expected. However, on one occasion someone from a group of retirees distributed leaflets printed with

\footnotetext{
${ }^{30}$ Mentioned by Mariusz Jastrząb, interviews, 26 and 27 March 2016

${ }^{31}$ Observed by Agnieszka Popławska, interview 11 May 2016.

${ }^{32}$ Interview with Anna Kraus, 31 March 2016.

${ }^{33}$ Interview with Julia Chimiak, 16 March 2016.
} 
various slogans, including "Do not lie about Jedwabne." Occasionally, guides hear opinions such as "But the Germans did it" or "The Jews collaborated with the Soviets." (The alleged Jewish betrayal during the Soviet occupation is the most recurring theme of the conversation about Jedwabne.) I have noticed that participants of senior (U3A) ${ }^{34}$ groups are most prone to holding such opinions. Most often, however, groups do not speak with one voice, and someone from the group rather than its guide objects to such statements. I have been interrupted only two or three times while talking about Jedwabne during the eighteen months of my work at the core exhibition, always by Polish visitors accompanying a group of foreigners.

The topic of the pogroms in Jedwabne and the neighbouring towns has constituted an integral part of the public discourse in Poland for a dozen or so years. Nonetheless the level of knowledge about their causes, circumstances, and the numbers of casualties still remains relatively low and, in addition, information is provided by news outlets rather than academic sources. This pervasive frame of reference highlights the symbolic importance of the gallery, especially since the average person would not travel to Jedwabne to face the complicated past by standing at the foot of the monument erected there.

By contrast, I have also heard visitors commenting that the history of Jedwabne in presented in a very understated way; the map of the pogroms does not arouse any controversies either. ${ }^{35}$

Some Warsaw residents inquire about the Ringelblum Archive ("Was it found after the war?", "Where are the documents now?"). They also ask about Judenrats ("How has Adam Czerniaków been judged?") and about Chaim Rumkowski and chairmen of other ghettos. ${ }^{36}$

Of course I do not assume that the groups I have shown around are representative of the entire Polish population. The decision to come to the museum usually indicates a certain openness and readiness to entertain another point of view. ${ }^{37}$

\footnotetext{
${ }^{34}$ Mariusz Jastrząb voiced a similar opinion, interview 26 and 27 March 2016.

${ }^{35}$ Conversation with a group from Żyrardów, 15 May 2016.

${ }^{36}$ Ibidem.

${ }^{37}$ I participated in the three-day project entitled 'Museum-on-Wheels' during the 'Woodstock Stop' festival in 2015. Over the course of three days, more than two thousand unprompted guests stopped by our pavilion. They were unprepared, often not realising at first that we were representing the Polin Museum. Their questions and opinions were challenging (and frequently stereotypical) and, at times, anti-Semitic, of the kind we had not heard from the regular visitors to the Museum. My colleague Mariusz Jastrząb made a similar observation. The travel agency survey conducted for the museum in April 2016 showed that groups of Polish tourists often turn down an offer to visit the Polin Museum, seeing it as something foreign and 'not Polish'. Some maintain that the reluctance towards the museum might arise from subconscious anti-Semitism on the part of tourists and the tendency to see the museum as focusing on a heritage that is not their own.
} 
Holocaust survivors constitute a very distinctive category of museum visitors. Sometimes they accompany groups that participate in the March of the Living. For some, it is the first visit to Poland after many years. Such tours usually take longer. Survivors frequently share their experiences with their guide and sometimes ask moving questions. "Do you display a map of the sewers that shows the escape routes?", asked a person who had survived and managed to get out of the burning ghetto through the sewers. ${ }^{38}$

\section{Groups from abroad}

Showing international groups around differs from working with Polish guests. The guides need to provide them with additional historical context and facts (concerning the German and Russian occupations, the Polish Governmentin-Exile, or the Polish Secret State), which are mostly unknown to foreigners. The level of knowledge about the Holocaust is also quite lacking. Julia Chimiak gives us the following example: "I showed a group of French Jews around lately. They had difficulties understanding that Poland under the German occupation was divided into two parts: the Generalgouvernement (GG) and the territories incorporated into the Third Reich. They thought that the GG had been similar to the Vichy government." ${ }^{39}$

Due to their limited knowledge, non-Jewish groups (but sometimes Jewish groups also) ask such basic questions as: "What is a ghetto?", "What did it mean to be closed in the ghetto?", "Did Polish people live in the ghetto, too?",'Were ghettos located only in the Polish occupied territories, or were they elsewhere, too?", "Why were the extermination camps set up on the Polish territory?", "What is the difference between a concentration camp and an extermination camp?"

Both Polish and foreign guests wish to know whether Germans come to the museum, and how they react to the gallery's content. Regarding this topic, multiple complex questions about the process of coming to terms with the past in Germany may arise. I myself have not shown German speaking groups around, but Agnieszka Popławska has, and here are some of her observations:

These groups usually come from Germany, seldom from Switzerland. I do not remember any group from Austria. By and large, they are made up of retired people, over sixty years of age anyway, educated, with extensive knowledge of history, open-minded, and friendly. Several times, I have accompanied Polish-German groups, participants of a youth exchange programme. Usually, their expectations are not clearly defined, but they express a desire to see the $20^{\text {th }}$ century gallery. I remember a middleaged German woman who, after listening to my explanation that aiding was punishable by death in Poland, whole families had been shot dead

\footnotetext{
${ }^{38}$ Letter from a guide, Zhenia Nikolajewa, 15 May 2016.

${ }^{39}$ Interview with Julia Chimiak, 16 March 2016
} 
on the spot, commented on a similar situation in Germany, in which such a person would have been sent to a concentration camp and such punishment would have ended in death anyway. But other members of her group reacted by saying that this was not the same thing. Another time, when I talked about Polish-Jewish relations during the war, a young German expressed surprise on hearing my remark that only a minority had shown a tendency to help Jews: "But Poland has the highest number of the Righteous ones." [...] They do not ask many questions while in the Holocaust gallery. I think, [it is because] they are somewhat tired by the time we arrive there, but their attention is also focused on my words. ${ }^{40}$

The foreigners may already be familiar with the story of Jedwabne. They know that in this case the perpetrators were Poles. They know Gross's book Neighbours (this mostly applies to Jewish groups, but also to those from Sweden, as Jan Tomasz Gross's book has been translated into many languages including Swedish). They do not know, however, how much effort it required to initiate the discussion of this subject that began in Poland several years ago, or the role played by historians affiliated with the Polish Centre for Holocaust Research in this regard. A few times, I have heard foreign guests expressing the opinion that the subject of Jedwabne is 'concealed', is not exposed enough in the gallery. [They stated that] the map showing the beginning of the war between Germany and Russia is displayed in a conspicuous place, visible to anyone when leaving the gallery devoted to the topic of hiding, but the part of the exhibit devoted to Jedwabne is easy to miss. ${ }^{41}$ As the museum's visitors are not free from prejudice and bias, the guides must be prepared to deal with a variety of attitudes. Among the opinions expressed by the foreign participants of the 2016 March of the Living was the following "Please do not feed us propaganda; tell us how the Poles helped murder six million Jews." ${ }^{2}$

When a group is not familiar with the subject of collaboration, the guides try to modify their narrative. Barbara Subotko reminds her French groups of the debate about the collective memory of the Vichy regime initiated by the historian Robert Paxton. ${ }^{43}$ This analogy helps her to find common ground and convey the message. I personally refer to the debate, aroused by the book Hitler's Willing Executioners by Daniel Goldhagen, which is better known to my audiences.

Many foreign and Polish visitors alike cannot comprehend the Nazis' antiSemitism that was the key factor in the Holocaust. Some feel that the exhibition is missing an introductory section that traces the beginnings of the Third Reich in the 1930s. Jeremy Jones, a visitor from Australia, said: "the Interwar gallery I had visited before entering the Holocaust gallery was lacking provision of

\footnotetext{
${ }^{40}$ Interview with Agnieszka Popławska, 11 May 2016.

${ }^{41}$ From my own observations and conversations with some foreign visitors.

${ }^{42}$ From satisfaction surveys taken by participants in the March of the Living in 2016.

${ }^{43}$ Interview with Barbara Subko, 28 March 2016.
} 
a broader context for anti-Semitism." ${ }^{44}$ The Interwar gallery is designed to be seen before the Holocaust gallery, as it is, in theory, a place in which the audience can prepare for the next part of the exhibit. This may be the case for guided groups, but not necessarily for those who choose self-guided tours or audiotours. Some visitors said that the introductory section had not been thorough enough, and, as the subject [of anti-Semitism] is not adequately traced, viewers must jump from Poland's history in the interwar period to the broader field of world history. ${ }^{45}$ That is why they often ask such questions as: "Why did Hitler hate the Jews?" 46 or "What was the cause of World War II?" The gallery does not present historical knowledge at its most basic level, but focuses on more complicated historical issues, the understanding of which requires more knowledge than a typical visitor possesses.

Can the Holocaust gallery reveal anything new to Jewish groups from the United States or Israel? What distinguishes it from other Holocaust museums and sites of memory (lieux de memoire) in Poland and around the world? While visiting the museum, Jewish youth groups from the United States often decide to skip the Holocaust gallery because a programme of their week-long stay in Poland includes the trip to Auschwitz-Birkenau and sometimes even to another death camp. These groups have a basic knowledge of the Holocaust, and their organisers do not deem it necessary to include the gallery in their museum tour. The same applies to youth groups from Israel that usually visit the entire museum but not the Holocaust allery.

By contrast, Shmuel Afek, an educator ${ }^{47}$ who has cooperated with our Education Department regularly for years to bring Jewish youth groups from the United Stated to the museum, is convinced that the gallery is of vital importance in educating Jewish visitors.

I believe that the Holocaust gallery in [the] Polin Museum has exceptional educational potential that needs to be better presented to the visitors. In many ways, the exhibition assumes that the visitor will receive his/her general Holocaust education outside the museum, and therefore does not try to present the overall picture as is expected in Holocaust museums around the world. This enables the museum to view the Holocaust experience as part of the thousand year history of Polish Jewry, not as a separate event, and not as the end of the story of the Jews in Poland. This message, I believe, is crucial to the story that the museum wishes to tell, and this needs to be emphasised in any planning of group visits.

If that message is clear, the visitor can then focus on what differentiates this gallery from [other] Holocaust museums that s/he has or will visit in

\footnotetext{
${ }^{44}$ Interview with Jeremy Jones 7 April 2016.

${ }^{45}$ Interview with Barbara Subko, 28 March 2016.

${ }^{46}$ Interview with Anna Kraus, 31 March 2016.

${ }^{47} \mathrm{He}$ works as a social studies teacher at the Abraham Joshua Heschel High School in New
} York. 
the future. It is my understanding, that the Holocaust gallery at [the] Polin museum strives to tell the story of the Holocaust through the eyes of Polish Jews, primarily those who were in Warsaw during this time. Even though there is ample material about other aspects of the Holocaust in Poland, the focus on Warsaw and the way it is told, diary entries from Adam Czerniakow and Emanuel Ringelblum , are unique and deserving of time and reflection, especially for visitors who already have a background in [the] Holocaust but lack the [depth of] focus that the museum provides. ${ }^{48}$

The 2016 programme of the March of the Living included an optional tour of the Holocaust gallery. ${ }^{49}$ The gallery does not provide viewers with the basic facts but delivers deeper and more detailed knowledge. It focuses on Warsaw and, unlike other museums, concentrates on life in the shadow of death rather than on the atrocities of the time. This makes it different from the other sites of memory that the groups visit during their stay in Poland. Many participants of the March asked to include the gallery in their tour programme.

Data gathered from our internal evaluation survey, and from questions directed by visitors to their guides, indicate that the audience is primarily interested in learning about Jewish-Polish relationships and the roots of hatred of Jews.

Other topics that visitors stated interest in learning more about are as follows: Factors that produced the Holocaust, the Holocaust and evil, how did the Polish population react to the Holocaust? What motivated Poles who collaborated with the Nazis? What was the Jewish religious life like during the Holocaust? Why did some Jews wish to stay in Poland after the Holocaust?, and post-war antiSemitism. ${ }^{50}$

Some visitors indicated the lack of space for reflection that many of them needed to process their emotions after visiting such a place. They did not think that the void space of the corridor situated at the end of the gallery provided it. A discussion with their guide following the tour could be a way to cope with emotions, but, unfortunately, the guides generally do not have time for conversation, and so they are forced to leave visitors to themselves. Some visitors return to the museum seeking reconciliation with their feelings. ${ }^{51}$

Professor Matthew Lee of James Madison University, who brings American students interested in the topic of ethnic conflict and genocide to Poland annually, argues that it is essential to have such a place in the museum.

\footnotetext{
${ }^{48}$ From a letter from Shmuel Afek, 24 March 2016.

${ }^{49}$ The March of the Living is an educational programme established in 1988 for Jewish students (also attended by non-Jewish participants in recent years), that provides young people with the opportunity to visit sites of memory in Poland and Israel. The purpose of the March is to counteract anti-Semitism and strengthen Jewish identity. In May of 2016, 2,488 participants of the March of the Living visited the POLIN Museum from the United States, Latin America, South Africa and Europe.

${ }^{50}$ From satisfaction surveys taken by participants in the March of the Living in 2016.

${ }^{51}$ Interview with Anna Tokarska, 24 January 2016.
} 
"For many people, the feelings, emotions, and thoughts are still quite complicated and raw, and having a space in your museum to contemplate these ideas I have found to be effective in the US Holocaust Museum in Washington, DC as well as in Oskar Schindler's factory museum in Kraków. People need the time to process their reactions to the events even if they were only a witness), or if they are learning about the events for the first time." 52

\section{The Visitors from Eastern Europe}

Jewish history is completely unfamiliar to most visitors from Eastern Europe, including Moldovans and Ukrainians, so they discover many facts previously unknown to them in the museum. A conversation I had with history students from the Catholic University of Lviv, who visited the Polin Museum as a part of their study trip to Poland in 2016, ${ }^{53}$ revealed that hardly anybody knew anything about the pre-war Jewish history of their towns and cities (such as Kirovohrad, Buczacz, Tarnopol, and Kharkiv), or about what had happened to Jews during the war. They were only familiar with the history of Lviv. For many of them, the Holocaust gallery became the first place where they could openly confront the challenging aspects of their national history.

Here are some thoughts they shared with me during an hour-long discussion held after they had visited the permanent exhibition: "For us, visiting the Holocaust gallery was very emotional. It is well-designed. It is an example of how we could work and talk about the Jewish history in Ukraine", "Thank you very much for the museum. First of all, I think that the museum is a very important institution in Warsaw and, generally, in Poland. My only comment is that the Jewish history constitutes an important part of the history of the world, so perhaps it would be worthwhile to include more information about Jews from other cities, which were non-Polish?", "The Museum could widen its narratives by adding more [information] on the Jewish history of Ukrainian cities, about which we know so little." ${ }^{54}$ The subject of the pogroms in Lviv in the summer of 1941 still presents a challenge to Ukrainian groups. One of the visitors from that city, an academic teacher, commented that "the portrayal of the pogroms in Lviv needs to be more nuanced." 55 The Ukrainian public has still not confronted this aspect of its history, and the pogroms in Lviv, in which Ukrainian nationalists participated, are not commemorated in Ukraine. The involvement of the Ukrainian auxiliary forces in the Holocaust presents another difficult topic. Mariusz Jastrząb recollects: "I showed a group of Ukrainian women around once.

\footnotetext{
${ }^{52}$ Prof. Matthew Lee; e-mail message, 26 March 2016.

${ }^{53}$ Held in POLIN Museum, 21 April 2016. I am grateful to Małgorzata Berger who has organised the event.

${ }^{54}$ Ibidem.

${ }^{55}$ Ibidem.
} 
I remember very well their surprise when they read at the Umschlagplatz about the Ukrainian auxiliary formations. They didn't know anything about it."56

There is the Ukrainian Center for Holocaust Studies in Ukraine (managed by Anatoly Podolski) that has been active for years, history of the Holocaust training courses for teachers are being organised, and the subject is slowly finding its way into public discourse, but it still remains unknown to many. Professor Omer Bartov, who researched and described the role of local collaborators, has more than once been compared to Jan Tomasz Gross, even though his book, Erased. Vanishing Traces of Jewish Galicia in Present-Day Ukraine, has not triggered a debate similar to the one we witnessed in Poland.

The Polin Museum and especially the Holocaust gallery are of critical importance, as here the audience can become exposed to information that is not available elsewhere.

But this poses the next challenge: How to present difficult aspects of their national history to groups coming from Ukraine and Lithuania. Is it better to introduce the subject directly at a certain point? Or must we create an atmosphere of trust first by relating the experiences of other nations that have experience in confronting their past? The chief curator of the core exhibition, Prof. Barbara Kirshenblatt-Gimblett, believes that "As a portal, catalyst, and forum, [the] Polin Museum could offer an alternative model of constructive engagement and [a] trusted zone for critical reflection." 57

In this context, the Polish debate on Jedwabne aroused Jan Tomasz Gross's books could serve as a reference point to visitors from Eastern Europe in dealing with their own history, an example of how a nation can approach its complicated past and integrate it into the national narrative. The ability to do so is a sign of a society's maturity. Quoting Anne Applebaum: "As nations become more confident, it becomes easier for them to discuss difficult moments in their history. The more confident a nation is, and it feels itself a part of Europe, the more it speaks of what it has done wrong in the past. Of course, one should avoid generalisation, as different countries adopt different politics of memory. [...] Poland has already initiated debates on the pogrom in Jedwabne and on the fate of Jews during the war in general. Nowadays, such discussions become more open and honest.".58

The guides may have noticed that, while groups from Ukraine usually feel a need to discuss the painful aspects of the exhibition and share the emotions aroused by them, Lithuanian groups (I myself have given tours to several) often

\footnotetext{
${ }^{56}$ Interview with Mariusz Jastrząb 26 and 27 March, 2016.

${ }^{57}$ Sineaeva-Pankowska, "Wywiad z Barbarą Kirshenblatt-Gimblett"; Barbara KirshenblattGimblett, "Historical Space and Critical Museologies: POLIN Museum of the History of Polish Jews," in From Museum Critique to the Critical Museum, p. 147.

${ }^{58}$ Natalia Sineaeva-Pankowska, [interview with Anne Applebaum], Nigdy Więcej 19 (FallWinter 2011).
} 
lapse into silence and do not engage into a dialogue with their guide while viewing the part of the exhibition that tells the story of the Ponary massacre. Sometimes they seemed as though they had not expected to find a reference to Lithuania, and voiced their surprise at seeing the Ponary massacre mentioned at the Polin Museum at the Holocaust gallery.

Visitors from Romania, in turn, might draw a parallel between the Iași pogrom in June 1941, when tens of thousands Jews were murdered. This topic has only slowly begun to enter into public discourse in Romania, but it also inspires denial and results in an underestimation of the number of victims, or blaming the victims (alleging that Jews greeted the Red Army). According to Prof. Michael Shafir's clasification, this is an example of the trivialisation of the Holocaust.

A thorough debate such as the one that took place in Poland has not yet happened in Romania. I may use the Polish debates as a point of reference and an example while I guide the infrequent visitors from Romania. A number of pogroms also occurred in Moldova in July 1941; including the one that happened in its capital Chisinau/Kishinev after it had been captured by Romanian and German forces. But this incident remains mostly unknown, and has not yet become subject to public debate. Still, more research is needed to understand the role played by the local population. ${ }^{59}$ Seen from this vantage point, the Polin Museum gains universal significance as a place where the frail Eastern European memory of the Holocaust is being preserved.

The same is true of the aforementioned 'Shoah by bullets' site in Ponary. There are many such places in Lithuania, Belarus, Ukraine, and Moldova. Not all of them are even marked, and are often neglected and unknown today. Only a few of local people can still remember what happened there. Let us take as example Olanesti, a Moldovan village, in which Jews constituted nearly half of the population before World War II. The Romanian army, under the command of Marshal Ion Antonescu (that supported German military forces on the Eastern Front) executed 300 people there, all the Jewish inhabitants of the village. Today, practically no one knows about it in Olanesti, and the place of Jewish martyrdom has not been marked. The former rabbi's house, where the Jews were detained before the execution, has been severely vandalised, and, in a few years, nobody will remember that it was there. I visit the village every year. I take pictures to document its gradual destruction. There are more places like this one.

Irina Szyhowa, who runs the Jewish Museum in Chisinau (Moldova) said: "I personaly, as a director of a museum, think that the Polin Museum is a model of how to design a museum, how to strike a balance between narrative and objects, while for my country, and other Eastern European countries, it is also an example of how to rework painful subjects." ${ }^{\prime 6}$

${ }^{59}$ Natalia Sineaeva-Pankowska, "Pamięć o Holokauście w Mołdawii," Zagłada Żydów. Studia i Materiały 11 (2015).

${ }^{60}$ Interview with Irina Szyhowa, 30 March 2016. 
Russians and Belarusians are occasionally puzzled by the notion of the 'double occupation' of Poland introduced at the beginning of the gallery, because a very different version of the history is taught in their countries. The opinions of the Russian visitors were divided. Some commented that the outset of the war and consequences of the Molotov-Ribbentrop Pact had been very well depicted. ${ }^{61}$ Oleg Leikind of the Likhachev Foundation of St. Petersburg stated:

"The scope of the exhibit, and its well thought out layout have surprised us. Poland can be proud of it. Unfortunately, similar projects meet with opposition, or even hostility, from so called 'true patriots' and the authorities. In Russia, for example, it happens in the case of the Stalinist repressions or gulag museums." ${ }^{\prime 2}$ Others, however, stated that they found the beginning of the gallery to be incomprehensible and confusing. A teacher visiting the museum with a group of young people from Belarus 'corrected' me at the beginning of the tour while I was taking about the double occupation, and took it upon himself to explain to the group, which country really occupied Poland. So the question of how to tailor the narrative to the needs of such specific groups while keeping it consistent at the same time, poses another challenge for the guides.

To summarise, during the first eighteen months after the opening, the contents of the core exhibition and the Holocaust gallery were tested intensely by the team of museum guides during their interactions with visitors. Professors Barbara Engelking and Jacek Leociak have offered the team substantial intellectual support from the beginning.

Our first observations led us to believe that, despite the widespread belief that the Holocaust is the best-known event in the millennial history of Polish Jews, the level of knowledge about it is, in fact, rather low. Often, our visitors, Poles as well as foreigners, hold stereotypical opinions on various aspects of the Holocaust.

The gallery offers many opportunities for cooperation with visitors from all walks of life, students as well as elderly people, Poles and foreigners, Jews and non-Jews. For most of them, the gallery tour has not only been a deeply personal and emotional experience, but also a place where they are confronted by many difficult questions for the first time.

Some topics of the permanent exhibition are expanded by the so-called 'thematic walks'. I have co-created two such walks for Polish and foreign visitors: 'Shoah and its Commemoration' and 'Resistance Fighters'. These two-hour tours lead them through the final two galleries: Holocaust and Postwar Years - as well as a part of the interwar period gallery.

These walks enable visitors to expand their knowledge of such important topics as: anti-Semitism, persistence of stereotypes about Jews among Poles,

${ }^{61}$ In their opinion, the Polish debate on Jedwabne is a model of how to structure a debate on the Katyń massacre in Russia as so many Russians are unable to accept the truth about it.

${ }^{62}$ Interview with Oleg Leikind, 27 April 2016, after the tour. 
different attitudes adopted by Poles regarding the fate of Jews during World War II, and the postwar process of commemoration of the Holocaust. Since February 2016, the 'Shoah and its Commemoration' walk has remained a part of the museum's permanent resources, available on request for Polish and foreign visitors.

Translated by Elżbieta Olender-Dmowska

\section{Interviews conducted between January and May 2016 (selection):}

Shmuel Afek, educator, USA; personal and e-mail communication, March 24

Julia Chimiak, specialist in Romance studies, translator, guide and education specialist at the POLIN Museum; recording, March 16

Dr. Mariusz Jastrząb, historian, guide and senior education specialist at the POLIN Museum; recording, March 26 and 27 .

Jeremy Jones, visitor from Australia; personal communication, April 7

Anna Kraus, historian, guide and education specialist at the POLIN Museum; recording and notes made on March $31^{\text {st }}$.

Dr. Matthew Lee, psychologist, professor in the Psychology Department, James Madison University, Harrisonburg, VA, USA; personal and e-mail communication, March 26

Dr. Rafał Pankowski, sociologist and political scientist, Professor in Collegium Civitas in Warsaw, visitor; personal communication, April 15

Agnieszka Popławska, psychologist, guide and education specialist at the POLIN Museum; interview and notes, May 11

Barbara Subko, teacher, educator, freelance guide at POLIN the Museum; recording, March 28

Irina Szyhowa, Director of the Jewish Museum in Chisinau (Moldova); interview, March 30

Anna Tokarska, specialist in Polish studies, translator, visitor; interview, January 24 